\title{
THE POTENTIAL OF TALL GRASSES AS AUTUMN SAVED FORAGES UNDER HEAVY NITROGEN FERTILIZATION AND INTENSIVE GRAZING MANAGEMENT',
}

\author{
F. F. Wedin, R. L. Vetter, and I. T. Carlson $\dagger$
}

MidWESTERN United States has a temperate climate, more specifically described as subhumid and microthermal. Pasturing systems in this area have developed to take advantage of the normal seasonal growth pattern of perennial legumes and grasses. Thus, pasturing is practisea extensively from May through September (5 months). Limited grazing is available in April, October, and November.

Forage management research, reviewed by Smith (1964), has been fundamental to formulating practical rules which, if followed, will minimize winter-killing of perennial legumes in midwestern United States. However, the general management rule which suggests that perennial legume/ grass mixtures not be harvested or grazed during an autumn winter-hardening period may be misleading when extrapolated to management of perennial, cool-season, tall ' grasses grown without legumes and used for pasture. Most pasture and forage research workers in midwestern United States have had a part in promoting practices geared to maintain the legume and have thus inadvertently fashioned managements that disfavour the grasses in terms of maximum utilization. This is particularly so where it was assumed that grasses had completed their yearly growth pattern by mid-September.

The once-a-year, generous spring application of nitrogen (N) has also lowered, in one respect at least, the chances for the grasses to be utilized to the fullest. Several references (Peterson, 1947; Scholl and Llambias, 1966; Wedin et al., 1965) indicate the vexing problem of utilizing all the extra pasture grown in spring and early summer, this portion often comprising 65 to $75 \%$ of the annual yield.

* Journal Paper No. J-6465 of the Iowa Agriculture and Home Economics Experiment Station, Ames, Iowa. Project Nos. 1539 and 1559.

$\uparrow$ Professor of Agronomy, Associate Professor of Animal Science,; and Associate Professor of Agronomy. 
Thus, while minimizing machine and labour cost of applying $\mathrm{N}$ by using one application, neither desired distribution of forage yield nor reduced purchase price of $\mathrm{N}$ has been realized. In midwestern United States, $\mathrm{N}$ costs are maximized at corn-planting time.

Alternative pasture management schemes that redistribute seasonal forage production are needed. The tall grasses offer versatility when coupled with adequate, timely $\mathrm{N}$ fertilization. Wedin (1966) pointed out that forage of acceptable quality from the tall grasses can be provided at more than one key period of the year to meet needs of livestock being maintained for breeding, namely, beef cows, ewes.

An assessment of a continuing grazing trial in southern Iowa, along with consideration of other pasture and forage research data from Iowa, provides the framework for planning yearly supply programmes. In this light, the concept of using autumn-saved forage in a three-season pasture management system is presented.

\section{AGRONOMIC POTENTIALS OF THE TALL GRASSES}

During the last 8 years, the following grasses have been extensively studied in our work: reed canary grass (Phalaris arundinacea L.) , tall fescue (Festuca arundinacea Schreb.) , smooth brome (Bromus inerrnis Leyss.), and cocksfoot (Dactylis glomerata L.) .

TABLE 1: MEAN DRY MATTER YIELDS OF TALL GRASSES IN METRIC TONS PER HECTARE

(Ames, Iowa, 1967-8).

\begin{tabular}{|c|c|c|c|c|c|c|c|c|c|}
\hline $\begin{array}{l}\text { Early } \\
\text { Spring }\end{array}$ & & $\begin{array}{c}\mathbf{N} \\
\text { Applied } \\
\text { (kg/h } \\
\text { After } \\
\text { Larvest } \\
\text { rly J ur }\end{array}$ & a) & $\begin{array}{r}\text { C } \\
\text { After } \\
\text { Harves } \\
\text { (Aug. }\end{array}$ & $\begin{array}{l}\text { cksfoot } \\
2\end{array}$ & $\begin{array}{c}\text { Smooth } \\
\text { brome }\end{array}$ & $\begin{array}{c}\text { Species } \\
\text { Tall } \\
\text { fescue }\end{array}$ & $\begin{array}{c}\text { R eed } \\
\text { canary } \\
\text { grass }\end{array}$ & $\begin{array}{c}\text { M ea n } \\
\text { over } \\
\text { grasses }\end{array}$ \\
\hline (1) & + & 0 & & 0 & & & 2.11 & 2.78 & 2.53 \\
\hline (2) & + & 0 & $+t$ & 134 & $5.78 \quad 1.97$ & 3.216 .16 & 7.26 & 7.08 & 6.59 \\
\hline (3) 67 & + & 67 & + & 134 & 9.17 & 10.40 & 10.87 & 12.13 & 10.67 \\
\hline (4) 0 & $t$ & 0 & + & 269 & 6.19 & 8.09 & 8.85 & 8.97 & 8.03 \\
\hline (5) 134 & + & 134 & + & 269 & 9.64 & 11.97 & 12.15 & 14.17 & 11.97 \\
\hline (6) 0 & + & 0 & + & 538 & 7.85 & 9.44 & 10.13 & 12.35 & 9.93 \\
\hline
\end{tabular}

Harvest dates 1967: June 13, July 24, November 3

1968: June 4, July 25, November 9 
In 1967-8, these grasses were harvested at Ames, Iowa, in small plot studies wherein $\mathrm{N}$ was applied in one, two, or three applications in variable amounts (Table 1).

Although the mean dry matter yields over two years (Table 1) reached a maximum with reed canary grass at 14.0 metric tons/ha (15.9. metric tons of $12 \%$ moisture forage), the yield of reed canary grass on the same treatment was 16.9 metric tons/ha (19.2 metric tons of $12 \%$ moisture forage) in 1968.

TABLE 2: MEAN DRY MATTER YIELDS OF TALL GRASSES IN METRIC TONS PER HECTARE FOR FIRST (1) AND SECOND (2) HARVESTS"

(Ames, Iowa, 1968)

\begin{tabular}{|c|c|c|c|c|c|c|c|}
\hline \multirow[t]{2}{*}{$\begin{array}{l}\text { NApplied } \\
\text { August 1, } \\
1967 \\
(K g / h a) \dagger\end{array}$} & Cocksfoot & $\begin{array}{l}\text { Smooth } \\
\text { brome }\end{array}$ & $\begin{array}{r}\mathrm{T} \\
\text { fes }\end{array}$ & $\begin{array}{l}\text { all } \\
\text { cue }\end{array}$ & $\begin{array}{r}\mathrm{R} \\
\mathrm{car} \\
\mathrm{gr}\end{array}$ & $\begin{array}{l}\text { eed } \\
\text { lary } \\
\text { ass }\end{array}$ & $\begin{array}{c}\text { Mean } \\
\text { over } \\
\text { grasses }\end{array}$ \\
\hline & 12 & 12 & 1 & 2 & & 2 & 12 \\
\hline (1) & $1.14 \quad 0.56^{\prime}$ & $2.31 \quad 0.49$ & 1.39 & 0.38 & 0.69 & 0.99 & $1.38 \quad 0.60$ \\
\hline (2) 134 & $2.11 \quad 1.17$ & 1.610 .61 & 2.31 & 0.76 & 2.47 & 1.48 & $2.12 \quad 1.00$ \\
\hline (4) 269 & $2.29 \quad 1.57$ & 6.590 .90 & 2.56 & 1.17 & 4.93 & 2.02 & $4.09 \quad 1.42$ \\
\hline (6) 538 & $2.56 \quad 5.16$ & $6.46 \quad 3.59$ & 2.38 & 3.72 & 7.02 & 5.67 & 4.604 .54 \\
\hline
\end{tabular}

* Harvest dates in 1968 listed in footnote, Table 1.

$\dagger$ Treatments $1,2,4$, and 6 (Table 1) receiving no N early spring or after harvest 1.1968.

The high yield in 1968 on this particular treatment resulted, in part, from the heavy $\mathrm{N}$ application on August 1, 1967. From the first and second harvest yields of 1968 (Table 2), it is evident that the previous August 1, 1967, application had a marked effect on the yields in 1968 up to August 1 when the plots received their 1968 applications of $\mathrm{N}$.

Noteworthy points from Table 2 are: (a) The 538, 269, and $134 \mathrm{~kg} / \mathrm{ha}$ applications made on August 1, 1967, had carry-over effects in decreasing order; (b) Tall fescue and cocksfoot showed less response from residual $\mathrm{N}$ with only second-harvest yields of tall fescue and cocksfoot more than 3.3 metric tons; and (c) Smooth brome and reed canary grass benefited most from residual $\mathrm{N}$.

An evident conclusion is that better seasonal distribution of grass yield might well be obtained by substantial $\mathrm{N}$ applications around August 1. The excellent yields in the autumn, plus adequate forage in early and mid-summer, favour the August 1 application. The importance of moisture 
cannot be minimized when considering the autumn application of N. Colville et al. (1963) showed striking relationships for first harvest yields and rainfall where $\mathrm{N}$ was autumnapplied on smooth brome.

Although forage yields were maximized at $539 \mathrm{~kg} / \mathrm{ha}$, Ryan (1970) has recently indicated that $\mathrm{NO}_{3}-\mathrm{N}$ percentages in the autumn-saved forage at $538 \mathrm{~kg} / \mathrm{ha}$ of $\mathrm{N}$ reached above $0.20 \%$, a minimum level considered harmful to cattle and sheep.

\section{THE THREE-SEASON PASTURE SYSTEM}

Tall fescue, reed canary grass, smooth brome, and cocksfoot were seeded in pure stands in 1966 and grazed in a three-season pasture programme in 1967, 1968, and 1969.

The three-season term denotes that the pastures were grazed at two distinct periods each year, which included a portion of three seasons: I, Spring-summer (late April to August 1); and II, Autumn (mid-October to mid-December). With grazing of the tall grasses fertilized with $\mathrm{N}$ in this manner, livestock would come from some winter feeding programme to pasture. During the late summer-early autumn period when the grasses are allowed to recover, the cattle could be grazed on other types of pasture. Either the same cattle or others could graze the autumn-saved forage. The three-season pasture scheme thus contributes to a yearly programme.

The total annual application of fertilizer has been, in kg/ha: P-14 (33 $\left.\mathrm{P}_{2} \mathbf{O}_{2}\right) ; \mathrm{K}-56(67 \mathrm{~K} \cdot 0) ; \mathrm{N}-269$. All $\mathrm{P}$ and $\mathrm{K}$ has been applied in the spring, while, for $\mathrm{N}$ only, $45 \mathrm{~kg}$ are applied in early spring, this followed with $90 \mathrm{~kg}$ in June and $134 \mathrm{~kg}$ on August 1. In the three years of the study, grazing for approximately 95 days in the springsummer period has been followed by approximately 55 days of grazing in the autumn.

Each pasture, consisting of one of the four species, is divided by electric wire into a $2 / 3$ and a $1 / 3$ section. Grazing animals are rotated from one section to the other at approximate 3-week intervals during the spring-summer period. Thus each section is grazed twice. after which the cattle graze the entire pasture. The $\mathrm{N}$ applications follow the grazings, and clipping of residual forage is practised as needed. Tester animals are used throughout the study, with grazers added as needed from reserve pastures of like species. 
TABLE 3: ANIMAL PERFORMANCE AND CARRYING CAPACITY FOR THREE-SEASON PASTURE SYSTEM, 1967-1969

\begin{tabular}{clccccc}
\hline & \multicolumn{2}{c}{$\begin{array}{c}\text { Reed } \\
\text { Period of } \\
\text { Grazing }\end{array}$} & $\begin{array}{c}\text { Tall } \\
\text { fescue }\end{array}$ & $\begin{array}{c}\text { canary } \\
\text { grass }\end{array}$ & $\begin{array}{c}\text { Smooth } \\
\text { brome Cocksfoot }\end{array}$ & Mean \\
\hline $\begin{array}{c}\text { Average } \\
\text { daily } \\
\text { gain, kg }\end{array}$ & Spring-summer & 0.48 & 0.55 & 0.69 & 0.55 & 0.57 \\
Days/ha* & Autumn & 0.79 & 0.64 & 0.92 & 0.76 & 0.78 \\
& Spring-summer & 788 & 703 & 666 & 751 & 727 \\
& Autumn & 417 & 349 & 242 & 299 & 327 \\
Total gain/ha & Total & 1205 & 1052 & 908 & 1050 & 1054 \\
& Spring-summer & 380 & 388 & 457 & 413 & 410 \\
& Autumn & 328 & 223 & 222 & 227 & 250 \\
& Total & 708 & 611 & 679 & 640 & 660 \\
\hline
\end{tabular}

"Grazing Periods Spring-summer

Autumn

$\begin{array}{lllr}1967 & \text { May 4-Aug. } 3 & \text { Oct. 23-Dec. } 18 \\ 1968 & \text { Apr. 25-Aug. 1 } & \text { Oct. 21-Dec. } 16 \\ 1969 & \text { May 1-July } 31 & \text { Oct. 10-Dec. } 5\end{array}$

Grazing results (1967-1969) for the three-season pastures are presented in Table 3. To date, results indicate the increased animal production possible in this system where the tall grasses are fertilized and managed to provide pasture at the extreme ends of an 8-month interval. Liveweight gains of $650+\mathrm{kg} / \mathrm{ha}$ under the three-season system exceed earlier maxima in Iowa experiments where pastures were grazed only during the traditional 5 months (May, June, July, August, September), with emphasis on forage managements favouring the legume in the sward.

In earlier studies, summarized by Wedin and Vetter (1970), liveweight gains in $\mathrm{kg} / \mathrm{ha}$ for various pastures are typified by: (a) 156 for unimproved, predominantly Kentucky bluegrass (Poa pratensis); (b) 240 for similar pastures receiving $67 \mathrm{~kg} / \mathrm{ha}$. of $\mathrm{N}$ annually; (c) 423 for birdsfoot trefoil (Lotus corniculatus); and (d) 488 for lucerne (Medicago sativa)/grass.

Increases in total liveweight gain under the three-season system likely result from several factors-primarily the management per se and the higher rates of $\mathrm{N}$ with timely application, The three-season management that permits fall grazing is significant as evidenced by the values for average daily gain in the autumn period (Table 3) when colder weather, cessation of plant growth, etc., might be expected to slacken animal gain rather than favour it.

Further indications of why tall fescue, less winter-hardy than smooth brome and reed canary grass, is very acceptable for autumn grazing in southern Iowa are discussed by 
Bryan et al. (1970). In our area where a high level of winter-hardiness is of lesser need for the perennial grasses, the yields and quality of tall fescue offer real promise. Smooth brome, though of good quality, is low-yielding in the autumn (Table 3). Our results indicate that tall fescue continues growth longer in the autumn. The concentration of water-soluble carbohydrates in the above-ground portions of tall fescue in the autumn (Wedin et al., 1966) enhances quality. Research in Virginia by Brown and Blaser (1965) suggests that the accumulation of soluble carbohydrates in tall fescue in the autumn is associated with photosynthesis exceeding requirements for respiration and growth.

Of the four grasses grazed, each has at least one favourable attribute. Thus, the choice of grass species may be decided on preference (Table 4).

TABLE 4: RANKING OF TALL GRASSES + N FOR PASTURES

\begin{tabular}{llclc}
\hline & TF & RCG & SB & CF \\
\hline Stand establishment & 2 & 4 & 3 & 1 \\
Winterhardiness & 3 & 2 & 1 & 4 \\
Forage quality: & & & & \\
$\quad$ Spring-summer & 4 & 3 & 1 & 2 \\
$\quad$ Autumn & 1 & 3 & 1 & 2 \\
Yield: & 3 & 1 & 2 & 4 \\
Spring-summer & 1 & 2 & 4 & 3 \\
$\quad$ Autumn & $\mathbf{2}$ & 1 & 1 & $\mathbf{2}$ \\
Earliness & & &
\end{tabular}

\section{THE THREE-SEASON SYSTEM AS PART OF A TOTAL} PROGRAMME

From the many pasture and forage research studies available in Iowa work, Wedin and Gay (1969) converted grazing data with steers to beef cow-calf days to facilitate consideration of pasture and forage programmes that would provide the yearly total digestible nutrients (TDN) needs for a beef cow-calf unit (spring calving), allowing sufficient TDN to wean a $260 \mathrm{~kg}$ calf. In a practical context, 100 such cow-calf units were considered, with an excess TDN of $15 \%$ included to cover needs of replacement animals and to insure against unfavourable weather conditions.

One possible programme out of many is presenited in Table 5. The number of hectares needed to provide the annual needs of the 100 cow-calf group are listed. The mix of pasture types and managements thereof (Table 5) are drawn from 45 individual types of pastures or management. Note that the tall grasses used in a three-season pasture 
TABLE 5: A YEARLY PASTURE-FORAGE PROGRAMME FOR BEEF COW-CALF* PRODUCTION

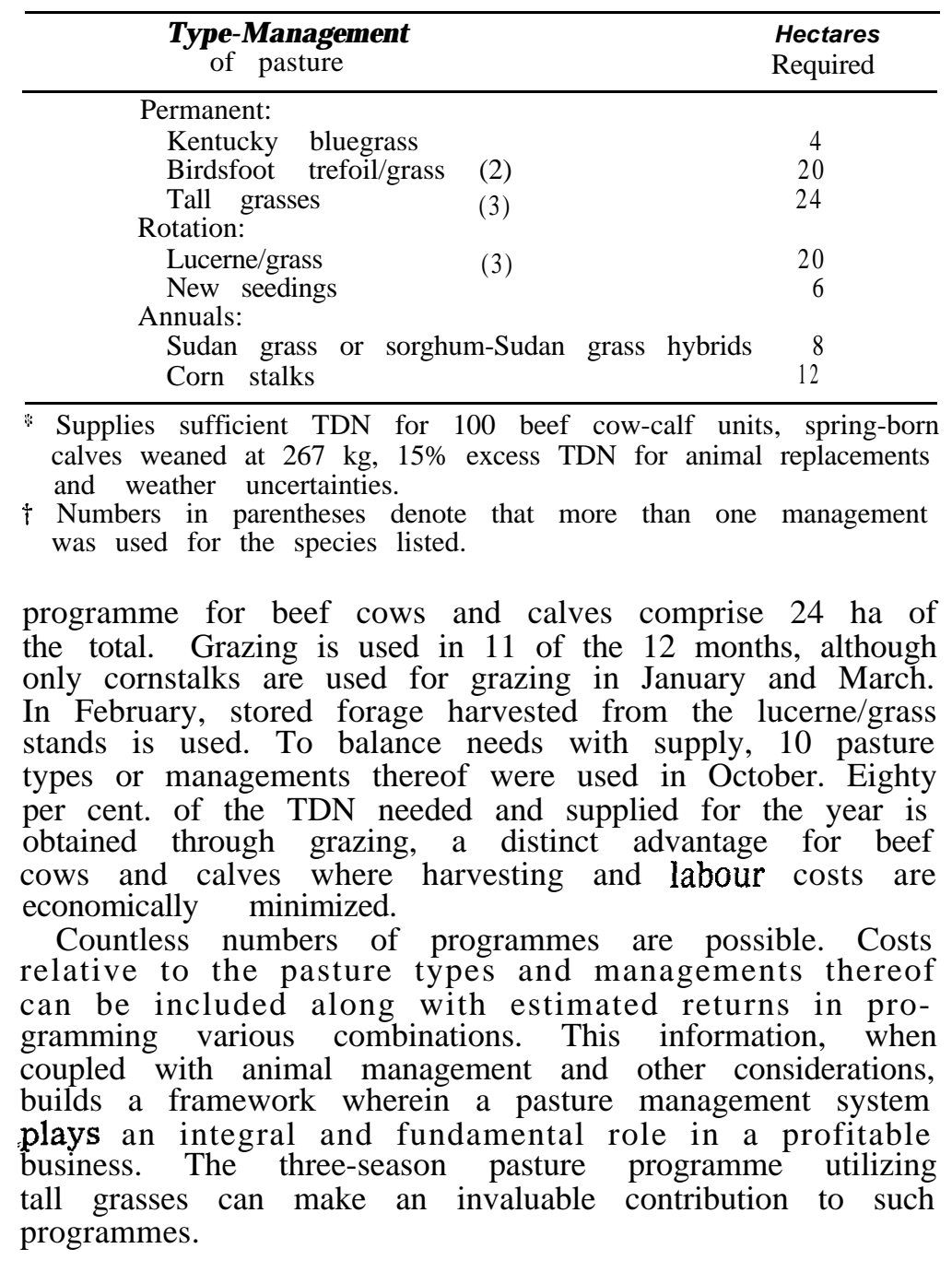

\section{REFERENCES}

Brown, R. H.; Blaser, R. E., 1965: Crop Sci., 5: 577.

Bryan, W. B.; Wedin, W. F.; Vetter, R. L., 1970: Agron. J., 62: 75. Colville, W. L.; Chesnin, Leon; McGill, D. P., 1963: Ibid., 55: 215. Peterson, Maurice, 1947: J. Am. Soc. Agron,, 39: 412. 
Ryan, Michael J., 1970: Nitrates in forage grasses as affected by time and level of nitrogen application. Unpublished Master of Science Thesis, Iowa State University, Ames, Iowa

Scholl, J. M.; Lambias, C., 1966: Proc. 9th int. Grassld Congr.: 1335. Smith, Dale, 1964: Herb. Abstr., 34: 203.

Wedin, W. F., 1966: Proc. 9th int. Grassld Congr.: 1163.

Wedin, W. F.; Donker, J. D.; Marten, G. C., 1965: Agron. J., 57: 185.

Wedin, W.F.; Gay, Nelson, 1969: Potential for forage production and utilization by the beef cow herd in lowa. Mirneo. paper from cow-calf seminar. College of Agriculture, Iowa State University, Ames, Iowa.

Wedin, W. F.; Vetter, R. L., 1970: Proc. 11th int. Grassld Congr.: 842. Wedin, W. F.; Vetter, R. L.; Carlson, I. T., 1966: Proc. 10th int. Grassld Congr.: 424

\section{DISCUSSION}

O'Connor asked if there was any possibility of improving Phalaris arundinacea, in view of its high yield in the autumn and also if any measurement had been made of nitrogen recoveries from heavy autumn applications. Wedin replied that Carlson was endeavouring to produce a new cultivar of $\mathbf{P}$. arundinacea but was not yet to the stage where he could release it. No measurement of nitrogen recoveries had been made but they were looking at $\mathrm{N}$ pollution in Western Iowa. They must also consider the losses of nitrogen Marten (U.S.A.) commented that trials in Minnesota had compared P. arundinacea with Bromus inermis and under heavy grazing had obtained similar liveweight yields. He thought improved' digestibility and intake should be considered in any breeding programme, together with an endeavour to reduce alkaloid content and thus improve palatability. Smetham inquired why a legume had not been used in association with the grasses, to which Wedin replied that it was not a legume-based experiment. Trefoil had been compared in several other trials. There was a need to evaluate the possibilities of the use of nitrogen because, with its high cost, it had to be economic. Some farmers, of course, did not want legumes because of the danger of bloat. Asked by Campbell what criteria were used in deciding on his stocking rates, Wedin stated that these had been set subjectively. They had used test animals and then adopted rates based on the data available. If more animals wer nocded to cope with grass they were put on. To a question from Langer concerning the nitrogen content of the autumn-saved pasture, Wedin said that it dropped from about $16 \%$ in mid-autumn to approximately $5 \%$ in December. 